\title{
BAGAIMANA MAHASISWA MEMBACA LEBIH PRODUKTIF?
}

\author{
Agus Sutanto \\ Pendidikan Biologi FKIP Universitas Muhammadiyah Metro \\ E-mail: sutanto11@gmail.com
}

\begin{abstract}
Reading is an important activity for a student to complete his studies. Nevertheless there are still many students not have good reading skills. A good reading would be more productive and effective produce quality students. Various methods have been formulated by experts, which is best depending on the student to choose which best suits his interests.
\end{abstract}

Kata kunci:: aktivitas, membaca, metode

Salah satu tugas mahasiswa yang harus dilaksanakan adalah membaca buku selain mengikuti kegiatan kuliah. Tugas ini merupakan pekerjaan yang paling banyak memakan waktu dan memerlukan energi bagi mahasiswa. Menurut William (2007) sekitar 85 \% dari seluruh studi di Perguruan Tinggi Amerika Serikat meliputi membaca. Aktivitas membaca bukan hanya beban perguruan tinggi yang luas dan berat, melainkan lebih dari pada itu membaca merupakan sebuah ketrampilan pokok yang paling utama di perguruan tinggi. Walter (2008) bahkan menggolongkan sebagai kerampilan pokok yang terus menerus diperlukan (the basic on going skill). Ketrampilan membaca tidak hanya sangat dibutuhkan di perguruan tinggi saja, melainkan kelak setelah selesai pendidikan tinggi dan bertugas dimanapun masih tetap diperlukan. Abad ke 21, banyak informasi direkam dan dikomunikasikan melalui kata tercetak. Salah satu wahana dalam upaya meningkatkan pengetahuan dalam rangka menguasai informasi dan perkembangan teknologi adalah kegiatan membaca. Kegiatan membaca bukan saja mengasyikkan, tetapi juga berarti menelusuri pengalaman pembelajaran melalui bahan bacaan. Hal ini dikarenakan bacaan merupakan ekspresi dari bahasa manusia sebagai suatu sistem komunikasi sosial yang mewakili kemajuan kemampuan kognitif manusia tertinggi (Semiawan, 1999).

Manfaat dari kegiatan membaca telah banyak diungkap oleh para pakar berbagai bidang disiplin ilmu. Walaupun demikian, kegiatan membaca tidak luput dari pengaruh faktor lain yang membuat seseorang terhambat bahkan tidak melakukan kegiatan ini. Dilihat dari kegiatan membaca, mereka membutuhkan stimulus yang membuat mereka terdorong untuk melakukan kegiatan membaca. Belum banyak orang tua dan dosen yang secara sengaja memberikan penghargaan saat mahasiswa melakukan kegiatan yang baik, seperti saat belajar dan membaca (Kompas, 2003). Walaupun peningkatan bahan-bahan cetak melimpah di negaranegara maju, hal ini sangat jauh berbeda keadaannya di dunia sedang berkembang apalagi dunia terbelakang (Badan Pertimbangan dan Pengembangan Buku Nasional. (1999).

Mengingat begitu pesatnya informasi yang disajikan dalam bahan cetak, di samping minat bacanya ditumbuhkan, keterampilan membaca mahasiswa perlu ditingkatkan. Hasil Studi Kemampuan Membaca yang dilakukan oleh Pusat Penelitian Balitbang Departemen Pendidikan dan Kebudayaan tahun 1992 melaporkan kemampuan membaca anak 
Indonesia menduduki peringkat ke 29 dari 30 negara yang diteliti (Soekarman dan Wardaya, 1992). Membaca merupakan suatu proses membangun pemahaman dari teks yang tertulis (Smith, 1988). Membaca merupakan suatu keterampilan yang kompleks yang melibatkan serangkaian keterampilan yang lebih kecil lainnya (Ahuja, 1999). Dengan kata lain, proses membaca adalah proses ganda, meliputi proses penglihatan dan proses tanggapan. Sebagai proses penglihatan, membaca bergantung pada kemampuan melihat simbol-simbol.Oleh karena itu, mata memainkan peranan penting (Wassman \& Rinsky, 1993). Sebagai proses tanggapan, membaca menunjukkan interpretasi segalasesuatu yang kita persepsi. Proses membaca juga meliputi identifikasi symbolsimbol bunyi dan mengumpulkan makna melalui simbol-simbol tersebut (Ahuja, 1999). Oleh karena itu, membaca dapat disimpulkan sebagai suatu proses yang melibatkan penglihatan dan tanggapan untuk memahami bahan bacaan yang bertujuan untuk memperoleh informasi atau mendapatkan kesenangan. Dengan ketrampilan membaca itu setiap mahasiswa akan dapat memasuki dunia keilmuan yang penuh pesona, memahami khazanah kearifan yang banyak khidmat, dan memperkembangkan berbagai ketrampilan lainnya yang amat berguna untuk kelak mencapai suskes dalam hidup. Aktivitas membaca yang terampil akan membukakan jendela pengetahuan yang luas, gerbang kearifan yang dalam, dan lorong keahlian yang lebar masa depan. Aktivitas dan ketrampilan membaca itu tidak dapat diganti dengan metode-metode pembelajaran lainnya. Seorang mahasiwa tidak mungkin lulus dari perguruan tinggi hanya dengan mengikuti kuliah saja. Ia mungkin saja dapat lulus dari satu-dua mata kuliahnya dengan menghafal dan tanya jawab dalam buku. Tetapi sudah pasti mahasiswa itu tidak akan menjadi seorang sarjana yang berbobot tanpa membaca sendiri jerih payah puluhan buku pelajaran yang mencapai puluhan juta perkataan.

Dengan demikian, membaca merupakan tugas utama, ketrampilan pokok, dan aktivitas yang penting bagi semua mahasiswa harus dipelajari dan dipahami seluk beluknya. Salah satu segi yang terpenting ialah metode membaca. Dalam buku-buku ketrampilan studi luar negeri, terutama dari Amerika Serikat, hingga kini telah dipaparkan berbagai metode, teknik, hampiran atau langkah membaca yang khusus diperuntukkan bagi studi terhadap buku kuliah. Aktivitas membaca buku kuliah lazimnya dikenal sebagai pembacan ragam studi (study type of reading) untuk dibedakan dengan membaca yang bercorak hiburan (recreational reading) seperti misalnya membaca buku cerita dan dengan membaca yang bertujuan memperoleh informasi secara cepat (quick-refernce type) seperti dalam hal membaca surat kabar.

Menurut Huthcroft

kemampuan membaca sesorang ada tiga kategori, yaitu: (1) Tingkat independen. Pada tingkat ini, anak dapat menguasai sedikitnya $90 \%$ bahan yang dibaca. Tingkat ini digunakan untuk membaca penelitian dan membaca kesenangan. (2) Tingkat instruksi. Pada level ini pemahaman mencapai $75 \%$. Tingkat ini memberi kesempatan kepada pendidik untuk membangun keterampilan berpikir dan kemampuan pemahaman peserta didik. (3) Tingkat frustrasi. Pengenalan kata hanya 90\% atau kurang sehingga mengakibatkan kegagalan memahami walaupun hanya setengah dari

bahan pelajaran. Pembaca lambat cenderung tidak menyukai membaca sebab bagi mereka kegiatan membaca memakan banyak waktu (Ahuja, 1999). Oleh karena itu, mereka sedikit membaca dan konsekuensinya tidak pernah cukup berlatih untuk meningkatkan kegiatan membaca. Ini selanjutnya menambah masalah karena mereka juga gagal menambah 
perbendaharaan kata mereka. DEngan demikian untuk trampil membaca seseorang harus memiliki keterampilan dasar membaca yaitu kemampuan-kemampuan pokok yang mencakup kemampuan mekanik (surface structure) dan kemampuan-pemahaman (deep structure) dalam waktu tertentu. Sajian berikut mepaparkan beberapa metode membaca antara lain: SQ3R, PQRST dan OK5R serta metode lainnya sperti STUDY, PERU, RTP, khususnya bagi mahasiswa untuk memperoleh pengetahuan yang diperlukan dan tidak ketinggalan zaman dalam studinya.

\section{BERBAGAI METODE MEMBACA}

\section{Metode SQ3R}

Cara lama bagi seorang mahasiswa dalam mempelajari buku pelajaran ialah seperti halnya kanak-kanak terus membuka buku dan membacanya dari halaman pertama sampai halaman terakhir. Bilamana isi buku belum dipahami sepenuhnya, pembacaan buku diulang lagi seperti semula, kalau perlu sampai beberapa kali. Dengan cara ini pikiran dianggap seperti kertas penghisap tinta. Pikiran dalam bentuk kertas itu diarahkan pada halaman buku lembar demi lembar dari waktu kewaktu dengan harapan kalimat-kalimat pada tiap halaman buku itu akhirnya akan tersedot melekat pada pikiran. cara demikian ini keliru dan mahasiswa yang mempraktekannya tidak maju dalam studinya.

Untuk berhasil menguasai isi sesuatu buku pelajaran, mahasiswa harus menjalankan aktivitas membaca untuk studi (reading for study) yang secara aktif seolah-olah bergulat dengan buku pelajarannya. Setelah bertahun-tahun melakukan penyelidikan dan percobaan, seorang guru besar psikologi Francis P. Robinson (2003) menyarankan suatu metode pembacaan studi yang kini sangat terkenal dengan singkatan SQ3R. Aktivitas membaca ragam studi yang efektif terhadap buku pelajaran meliputi 5 langkah yang berikut:

Survey (menyelidiki)
Question (menanyakan)
Read (membaca)
Recite (mendaras)
Review (mengulangi)

a. Survey: dalam langkah pertama ini mahasiswa memeriksa judul-judul paragraf atau bagian dalam setiap buku pelajarannya. Bilamana pada akhir bab terdapat ringkasan, bacalah ringkasan itu. Dengan langkah menyelidiki ini dapat diketahui di muka beberapa ide inti (core ideas, biasanya 3 sampai 6 buah) yang menjadi pokok-pokok pembahasan atau uraian seluruh bab itu. Ini kelak akan memudahkan mahasiswa menyusun dan memahami ide-ide keseluruhannya sewaktu membaca buku pelajaran yang bersangkutan.

b. Question : Langkah kedua dalam membaca untuk studi ialah mengajukan pertanyaan-pertanyaan sebelum mulai dengan pembacaan seluruh bab. caranya ialah dengan mengubah judul-judul paragraf itu menjadi berbentuk pertanyaan (cukup dalam pikiran saja). Pertanyaanpertanyaan itu akan membangkitkan keingitahuan mahasiswa, menonjolkan butir yang penting, menghubungkan dengan pengetahuan yang telah dimiliki mahasiswa, dan akhirnya meningkatkan pemahaman dan mempercepat penguasan seluruh isi bab.

c. Read: Membaca ragam studi bukanlah menyusuri baris-baris kalimat secara pasif,melainkan aktivitas untuk mencari jawaban terhadap pertanyaan-pertanyaaan yang telah diajukan dalam pikiran termaksud di atas. Jadi seorang mahasiswa mulai membaca paragraf pertama artikel dewan redaksi itu untuk mengerti faktorfaktor, hal-hal atau sebab-sebab apakah yang mengakibatkan kegagalan dalam studi di perguruan tingi. Dengan kesiapan perhatian dan rasa ingin tahu itu, maka jawabannya tampak seperti ditonjolkan oleh pagina buku. 
d. Recite: Setelah selesai membaca paragraf pertama dari bab dalam buku pelajarannya, mahasiswa perlu berhenti membaca dan tanpa melihat halaman buku lalu mendaras (mengucap kembali) dengan suara lantang jawaban yang telah ditemukannya dalam pembacaan.

Pendarasan itu boleh dilakukan secara singkat saja dan dengan kata-kata sendiri yang tidak perlu persis sama seperti yang tertulis dalam buku. Bilamana belum bisa ingat semua butirnya, boleh melihat kembali pagina buku yang telah dibaca. Dengan contoh yang didaftar di atas, seorang mahasiswa hendaknya berusaha menyatakan ke luar pemahaman dalam pikirannya bahwa menurut penyelidikan Resnick-Jordan ada 5 sebab dan menurut studi Lindgren ada 4 sebab (dengan menyebutkan perinciannya) bagi kegagalan studi mahasiswa. hal ini lebih baik bila dituliskan pada lembar catatan.

e. Review: Setelah satu bab selesai dibaca seluruhnya menurut langkah 3-4 itu, mahasiswa perlu mengulangi melihat seluruh lembar catatannya untuk menghubungkan semua butirnya satu sama lain dan kemudian berusaha mengingatingat kembali perincian masing-masing ide inti. Dengan langakh terakhir ini seluruh ide inti dalam bab itu berikut butirbutir perinciannya semakin kokoh ditanamkan dalam pikiran seseorang mahasiswa, sedang segenap susunan uraian bab juga dapat menjadi lebih jelas.

\section{Metode PQRST}

Metode membaca untuk study yang efektif dari Robinson tersebut di atas kemudian mengilhami berbagai metode pembacan yang dikemukakan oleh ahli-ahli lain atau dianut oleh sesuatu perguruan tinggi di Amerika Serikat dengan penyempurnaan uraian, penambahan langkah atau perubahan sebutan saja. Salah satu variasi metode membaca itu dikemukakan Thomas (2004) dengan singkatan PQRST untuk memudahkan ingatan. Langkah tersebut adalah:

$\begin{array}{ll}\text { Preview } & \text { (menyelidiki) } \\ \text { Question } & \text { (menanyakan) } \\ \text { Read } & \text { (membaca) } \\ \text { State } & \text { (menyatakan) } \\ \text { Test } & \text { (menguji) }\end{array}$

a. Preview: Langkah permulan studi membaca buku pelajaran ialah: menyelidiki sehingga diperoleh gambaran secukupnya mengenai isi sesuatu bab yang akan dipelajari. Penyelidikan itu dilakukan dengan membaca kalimatkalimat awal, kalimat-kalimat pokok pada permulaan atau akhir sesuatu paragraf atau ringkasan pada akhir bab itu (bila ada).

b. Question: Langkah kedua juga mengajukan pertanyaan-per-tanyaan. Bilamana pada akhir suatu bab oleh pengarangnya telah disusun suatu daftar pertanyaan untuk menguji pemahaman, hendaknya daftar ini dibaca terlebih dahulu sampai habis.

c. Read: Pembacaan perlu dilakukan secara aktif dalam arti pikiran seseorang mahasiswa memberikan tanggapan terhadap ide-ide yang dibacanya.

d. State: Dengan langkah ini seorang mahasiswa setelah selesai membaca hendaknya menyatakan dengan kata-kata sendiri ide-ide pokok yang telah dibaca dan dipahaminya.

e. Test: langkah kelima dan terakhir dalam metode membaca dari station ialah menguji apakah pikiran masih ingat ide-ide yang telah dibaca itu. Dalam hal ini seorang mahasiswa mengulangi bahan bacaannya sambil pikirannya berusaha mengingatingat ide-ide pokok yang terdapat di dalamnya.

\section{Metode OK5R}

Walter Pauk

(2004), memperkembangkan untuk mahasiswa metode mempelajari suatu buku pelajaran yang disingkat OK5R. Metode ini yang dianggap sebagai sebuah hampiran sistematik untuk menguasai bab-bab buku pelajaran selengkapnya mencakup langkahlangkah berikut: 


$\begin{array}{ll}\text { Overview } & \text { (menyelidiki) } \\ \text { Key Ideas } & \text { (ide-ide kunci) } \\ \text { Read } & \text { (membaca) } \\ \text { Record } & \text { (mencatat) } \\ \text { Recite } & \text { (mendaras) } \\ \text { Review } & \text { (mengulangi) } \\ \quad \text { Reflect } & \text { (merenungkan) }\end{array}$

a. Overview: langkah pertama ialah memandang sekilas judul-judul dan sub judul- sub judul yang terpampang sepanjang bab dalam buku pelajaran. Usahakan memperoleh gambaran yang besar mengenai ide-ide yang dibahas, problem-problem yang diungkap, dan pertanyaan-pertanyaan yang diajukan, sebelum mulai membaca.

b. Key ideas: semua buku pelajaran terdiri dari ide-ide utama, bahan-bahan pendukung, dan kata-kata perpindahan. Tugas utama setiap mahasiswa sewaktu membaca ialah memisahkan ide-ide utama dari kumpulan bahan pendukungnya.

c. Read: membaca setiap kali satu paragrap pendek atau satu alinea saja untuk menemukan ide utamanya.

d. Record: selama melakukan pembacaan seorang mahasiswa hendaknya mencatat pemahamanya terhadap bahan itu dengan menulis catatan di tepi pagina buku, menggaris bawahi kata/frasa kunci atau lebih baik lagi membuat ringkasan dari ideide utama dan bahan-bahan pendukung pada buku catatan tersendiri.

e. Recite: setelah selesai membaca satu alinie atau paragraf, mulaiah kembali mengucapkan kembali dengan kata-kata sendiri ide-ide utama dan bahan-bahan pendukung yang bersangkutan tanpa melihat halaman buku. Bila perlu boleh menggunakan catatan-catatan yang telah dibuat di tepi pagina sewaktu membaca tadi.

f. Review: setelah pendarasan seorang mahasiswa masih perlu menengok seluruh catatannya untuk memperoleh sebuah gambaran yang lengkap mengenai segenap ide yang telah dipelajarinya. Untuk mencegah ide-ide terlupakan lagi, pengulangan terhadap bahan pelajaran perlu dilakukan sewaktu-waktu.

g. Reflect: Langkah terakhir dalam metode membaca buku pelajaran pada Universitas Cornel ialah perenungan. Dalam hal ini mahasiswa mengilah ide-ide utama, melakukan pemikiran lebih mendalam, memperbandingkan ide-ide yang satu dengan ide yang lain, memperhatikan perbedaan dan persamannya, dan menyusun kembali menjadi kebulatan yang lebih besar atau meringkasnya menjadi satuan yang lebih kecil. Dan paling akhir sekali ide-ide yang baru dipelajari itu disatupadukan dengan pengetahuan yang sudah dimiliki dalam pikiran mahasiswa.

\section{Metod Study dari William Resnick dan David Heller}

Sebuah variasi lagi mengenai metode membaca buku pelajaran dengan lima tahap dikemukakan oleh William Renick dan David Heller (2004), dengan singkatan STUDY:

Survey the entire assigment (menyelidiki seluruh tugas bacaan)

Think of question (memikirkan pertanyaan-pertanyaan)

Understand your reading

(mengerti

bacaan anda)

Demonstrate your understanding (menunjukkan pemahaman anda)

You review the entire assignmen (anda mengulangi seluruh tugas bacaan)

a. Survey: tahap pertama mahasiswa menyelidiki pembagian bab dan paragrafnya, judul-judul yang tercantum dalam daftar isi, juga judul-judul pada gambar dan grafik. Kemudian membaca secara cermat ringkasan dan pertanyaanpertanyaan bilamana disusun oleh pengarang buku pelajaran. Tahap penyelidikan ini hendaknya memakan waktu 5 sampai 15 menit saja.

b. Think: Dalam pikiran hendaknya dipersiapkan pertanyaan terhadap bahan yang dibaca. Apa? Mengapa? Siapa? Bagaimana? Dimana? Bilamana ? Bila 
dianggap perlu pertanyaan-pertanyaan dapat dibuat secara tertulis.

c. Understand: Pembacaan dilakukan secara intensif sehingga mahasiswa mengerti sepenuhnya setiap perkataan dalam bahan bacaannya. Untuk ini dapat dibuat garis bawah pada kalimat, catatan ditepi halaman atau garis tegak disisi kalimat-kalimat penting. Hal-hal lainnya yang dianggap perlu juga harus dibikin, misalnya datar istilah dengan definisinya, tabel tanggal-tanggal, dan himpunan rumus-rumus penting.Untuk mencapai pemahaman bahan pelajaran yang tuntas, bila perlu uraian yang bersangkutan dibaca beberapa kali.

d. Demonstrate: Cara yang mendalam dan lebih memuaskan untuk menunjukkan pemahaman bahan bacaan itu ialah menjawab secara jelas, ringkas, dan cermat pertanyaan-pertanyaan yang dibuat. Ini sekaligus dapat menjadikan latihan bagi ujian mendatang dalam kelas.

e. You review: Pada tahap akhir mahasiswa mengulangi mempelajari bahan bacaannya sehingga dicapai tingkat belajar yang tuntas atau overlearning. Dalam hal ini mungkin perlu bahan pelajaran dibaca ulang secara lebih perlahan-lahan dan teliti.

\section{Metode-metode Membaca lainnya}

Dua metode lainnya yang tergolong serumpun dengan metode SQ3R tetapi perumusannya lebih singkat ialah PERU dan RTP. John Waldam (2005) membicarakan kedua metode tersebut.

PERU : Preview, Enquire, Read, Use.(menyelidiki, menanyakan, membaca, mempergunakan)

RTP : Read The Problem (bacalah persoalannya). Metode RTYP banyak diterapkan instruktur-instruktur latihan dilingkungan angkatan bersenjata. Ini terutama dipakai untuk memecahkan persoalan (reading for problemsolving).Dalam literatur kerampilan studi, khususnya teknik membaca buku, istilah "survey", "preview", dan overview", mempunyai makna yang sama sebagai langkah menyelidiki secara cepat dan selintas bahan pelajaran yang baru kemudian akan dibaca secara cermat kalimat demi kalimat. Masih dalam tahap sebelum pembacaan sesunggunya terhadap bahan pelajaran ialah menanyakan (question), yaitu mahasiswa disarankan membuat dan mengajukan pertanyaan-pertanyaan mengenai ide-ide yang akan dipelajarinya untuk membangkitkan rasa ingin tahu dan mengugah perhatian yang lebih besar.

Setelah selesai langkah pembacaan yang sesungguhnya, berlangsunglah tahap sesudah membaca yang menurut semua metode membaca yang telah dipaparkan dimuka diisi dengan langkah-langkah pendarasan (recite) dan pengulangan (review). John Waldam (2004) menyatakan bahwa semua metode membaca buku itu pada dasarnya menegaskan bahwa aktivitas membaca untuk studi adalah pembacaan untuk suatu maksud (reading for a porpuse). Dan biasanya maksud yang ingin dicapai itu ialah menjawab pertanyaan-pertanyaan dan memecahkan persoalan-persoalan. Bilamana setiap mahasiswa dari setiap aktivitas membaca buku-buku pelajaran dan bahan-bahan bacaan bisa menjawab pertanyaan atau memecahkan persoalan, maka hal ini berarti pengetahuannya telah bertambah.

\section{KESIMPULAN DAN SARAN}

Metode-metode membaca yang telah dikemukakan oleh berbagai ahli ketrampilan studi, pendidikan atau psikology memang cukup rumit dan membutuhkan jerih payah lebih besar sehingga mungkin nampak menjengkelkan bagi sebagian mahasiswa. Mungkin ada pula seorang mahasiswa Indonesia cerdas yang hampir lulus perguruan tingi dan dengan skeptis berpendapat bahwa metode-metode modern itu tidak banyak artinya karena selama ini ia lulus dengan membaca buku-buku yang lazim dikenal. Jadi, apa gunanya tambah ruwet dengan survey dan question sebelum membaca 
bahan atau melakukan recite setiap kali selesai membaca paragraf? Terhadap keragu-raguan ini cukuplah ditegaskan bahwa mahasiwa itu lupa kemungkinan mencapai prestasi lebih tinggi atau hasil lebih banyak yang dimilikinya. Memang berkat kecerdasannya dengan belajar dengan metode apa saja ia bisa terus lulus setiap semester dan sebentar lagi lulus sebagai sarjana. Tetapi andaikan, ia melakukan studi dengan metode-metode terbaik, maka pengetahuannya pasti akan lebih banyak dan mutunya tentu lebih tinggi serta kelak menjadi seorang sarjana yang jauh lebih hebat dari pada tingkat yang akan dicapainya. Kenyataan dan praktek dalam bidang-bidang lainnya seperti olah raga dan kesenian cukup membuktikan bahwa seorang yang berlatih dengan suatu metode yang baik dapat mencapai prestasi yang lebih besar dan mutu yang lebih tinggi.

Metode manakah yang terbaik yang dikemukakan oleh para ahli? Semua sama baiknya! Seorang mahasiswa yang mempunyai minat studi besar dan ketrampilan studi baik dapat memanfaatkan semua metode membaca buku itu sesuai dengan keperluan suatu saat. Untuk suatu buku pelajaran biasa mungkin dapat dengan SQ3R, tetapi untuk suatu mata pelajaran tertentu mungkin perlu ditambah dengan reflect, sedangkan terhadap suatu bidang pengetahuan mudah mungkin cukup dengan Read the Problem.

\section{DAFTAR RUJUKAN}

Ahuja, G.C. dan Pramila Ahuja. (1999). How to read effectively and efficiently.New Delhi: Sterling Publishers

Badan Pertimbangan dan Pengembangan Buku Nasional. (1999). Pembinaan perbukuan nasional, dua dasa warsa BPPBN 1978-1999. Jakarta
Francis P. Robinson (2003) Educational and psychological measurement and evaluation. Massachusetts:Allyn \& Bacon

Hutchroft, Diana M.R. (1981). Making languange work. A Practical Approach to Literacy for Teachers of 5-to 13-Year-Old Children. London: McGraw-Hill

John Wildam (2004). Reading process and practice. From sociopsycholinguistics to whole languange. USA: Portmouth, $\mathrm{N}$ Heinemann

Kompas, 26 Februari 2003 MAM. '’Buruk, penanganan anak jalanan,”

Semiawan, C. (1978). Lingkungan belajar yang mengundang suatu pendekatan bermakna dalam meningkatkan perkembangan anak retardasi mental. Disertasi.Jakarta: Institut Keguruan dan Ilmu Pendidikan

Smith E. (1988). Educational psychology. Teory and practice. MA: Allyn \& Bacon

Soekarman \& S.S. Wardaya (Ed.). (1992). Introduction to Asean librarianship.school libraries. Jakarta: The Asean Committee on Culture and Information

Stiggins, R.J. Merril. (1994). Student centered classroom assesment. New York: McMiller College Publishing Co.

Thomas (2004). Child development. New Delhi: McGraw-Hill

Walter (2008). Behavior modification: What It is and how to do it.NJ: Prentice-Hall 
Walter Pauk (2004). Behavior modification for the classroom teacher. USA: McGraw-Hill, Inc.

Wassman, Rose \& Lee Ann Rinsky. (1993). Effective reading in a changing world. New Jersey: Englewood Cliffs

Wiener, Harvey S. \& Bazerman, Charles. (2004). Reading skill handbook. MA: Houghton Mifflin

William Baker D. 2007. Reading Skills. Englewood Clifs, Prentice Hall, 8 th printing. 